\title{
THE NEUROPATHOLOGY OF TRAUMATIC PARAPLEGIA
}

\author{
A Critical Historical Review
}

\author{
By Lionel Wolman, M.A., M.D., Ph.D., M.R.C.P., D.P.M. \\ Department of Neuropathology, Royal Infirmary, Sheffield
}

Introduction. Although injuries to the skull and brain have a long and fascinating history reaching back to antiquity, the history of injuries of the spine and cord is relatively short and much less rich in examples. The probable explanation lies in the fact that such injuries were largely due to gunshot wounds until travelling at speed by rail, road and air became commonplace. The development of heavy industries, especially coal mining, has also contributed to the increased frequency of cases since the Industrial Revolution.

Early History. Probably the first reference to a fracture of the cervical spine with quadriplegia in medical literature was in the Edwin Smith papyrus published about 2500 B.C.E. by an unknown author who regarded it as an ailment not to be treated. Hippocrates recognised that spinal fracture could occur which might, or might not, be complicated by paraplegia and he attempted treatment by head traction. Although Celsus in his De Medicina remarked upon the hopeless prognosis of such paraplegic patients, Paulus of Aegina advised the removal of fractured laminae. Ambrose Paré operated for depressed splinters of bone or fragments impinging upon the cord and nerve roots as early as I549, using traction and pressure for reduction as in the Hippocratic method. Abernethy, however, regarded attempts at reduction as too dangerous.

In the past two centuries, one of the earliest cases to appear in the literature was reported by Maty in 1767 and occurred after a fall. Sir Charles Bell reported a similar case in I8I 7 while Sir Astley Cooper (I822) mentioned a case in his treatise on fractures and dislocations.

In the second half of the nineteenth century injuries to the spine increased in frequency so that the condition came to be known as 'Railway Spine'. The clinical syndrome was described in detail by Erichsen (I882) and his name was attached to the condition. Injury to the cauda equina was described by Thorburn (I888).

Concussion. Pathological observations on 'concussion of the spinal cord' were first reported by Abercrombie in 1828. Other cases were described by Mayo (I836) and Ollivier (I837), the lesions in the cord being verified after death. Concussion was introduced as 'a direct destructive action on specific nerve elements' by Obersteiner (1879), who described the changes in the spinal cord following shell explosions. Page (I885) severely criticised the writings of Erichsen and others, especially in their interpretation of the lesions in spinal concussion, without contributing anything constructive. Mott (I888) described a case labelled as 'concussion of the spine' in which wasting and paralysis of both arms with some sensory loss occurred after a fall. Spinal concussion was also described by Duménil and Petel (I885) and Clevenger (I889).

Schmaus (1890) was the first to study concussion experimentally. By repeated blows against a board attached to the backs of guinea-pigs and rabbits 
vertically suspended in the air, he produced circumscribed foci of softening, cavities and systemic degeneration in the spinal cord. The lesions were especially marked in areas directly exposed to the blows although foci were also scattered throughout the grey and white substance. As lesions were absent in the vertebrae and meninges, the spinal changes were ascribed to concussion. In the ensuing years several cases were reported as examples of concussion by Clutton (I89I), Clark (I892), MacDougall (I892) and Casamajor (I92I). In these, back trauma resulted in paraplegia, impaired sensation and retention. All these symptoms regressed in a few days and recovery was almost complete in two to six weeks.

Controversy, however, arose as to the occurrence of concussion in the spinal cord of man. Wagner (I896) concluded that the pathological condition in concussion of the spinal cord was to be found in alteration of nerve cells. Scagliosi (I898) found damage to the anterior horn cells in spinal concussion in the rabbit while Kirchgässer (I899) found considerable degeneration of medullary sheaths after a severe blow on the back without bony injury or haemorrhage in the rabbit. Nonne (I899) studied a case of traumatic paraplegia at autopsy two years after a blow on the lumbar region. The cord and vertebrae appeared normal with the stains employed so that the disturbance was believed to be functional, due possibly to degeneration of fibres in white matter in the early stages without subsequent gliosis. The subject of spinal concussion was reviewed by Schmaus (I899) with the conclusion that no perfectly satisfactory case of spinal concussion had been recorded in man. Spiller (1899) studied the spinal cord of the kitten after experimental blows to the back and found anterior horn cell changes minimal, but degenerative changes were seen in the white matter of anterolateral and ventral columns in the Marchi preparation.

Concerning the pathogenesis of spinal concussion, the view of Schmaus was that the force producing the concussion was transmitted to the perivascular spaces and central canal by the oscillations of the cerebrospinal fluid causing tears, and absorption of parenchyma. Similar views were expressed subsequently by Gussenbauer (1893) and Lhermitte (I915) although Henneberg (1915) blamed the blood vessels, especially capillaries, believing that interference with the blood circulation resulted in acute degeneration and necrosis of nerve elements. Thorburn (I887) believed that acute bending of the vertebral column which then righted itself, but not before great or irreparable damage was done to the cord, was a responsible factor. This idea of transient dislocations was supported by Kocher (1896), who thought every case of concussion was of contusion. Fickler (1905) attributed the cause to bruising of the cord when jarred, its fibres striking or pressing against each other or against bony structures.

Traumatic Haemorrhage. At the turn of the present century, Bailey (I900) in a comprehensive article on traumatic haemorrhages in the spinal cord outlined a syndrome caused by damage in and about the central part of the cervical cord following forcible flexion or extension of the neck without fracture or dislocation. The resultant paralysis of the forearms and hands was considered to be due to haemorrhage in the grey matter of the anterior horns destroying nerve cells, so that complete recovery was impossible. In contrast, the accompanying paralysis of the legs was caused by either pressure on the adjacent pyramidal tracts by the central haemorrhage or increasing oedema, both of which would permit recovery.

This syndrome has been reviewed more recently by Schneider et al. (I954). 
It occurred in both hyperextension and flexion injuries. Pathological confirmation was obtained in one case (Schneider et al., 1958). The reasons for designating the condition as the syndrome of acute central cervical cord injury and its differentiation from traumatic syringomyelia were discussed by Schneider and Knighton (1959).

Upper Cervical Injuries. In the first decade of this century interest in spinal injuries was focused on the upper cervical region and several articles were published on traumatic lesions of the atlas and axis vertebrae and their effects (Walton, I903; Corner, I907; Van Assen, I908; Pilcher, I910; Mixter \& Osgood, I9I0). Corner (1907) stressed the possibility of delayed myelopathy occurring with these injuries and included in his series a case of a young female who developed signs of damage to the upper cervical cord a year after sustaining a fracture of the odontoid process. Elliott and Sachs (I9I2) reported the autopsy findings in a man of 50 who sustained a fracture of the odontoid process 32 years previously. There was a pseudo-arthrosis of the body of the axis and the odontoid, which was ankylosed with the arch of the atlas. The spinal cord showed degeneration and atrophy of the crossed pyramidal tracts. The fact that injury to the various elements of the vertebral column could occur frequently without damage to its contained nervous elements was pointed out by Boeckel (I9I I), who collected 95 cases of fractured spine without cord injury. Jefferson (I920) reported four cases of fracture of the atlas vertebra and reviewed those previously recorded. He found 42 cases in the literature, and in 19 of these, signs of cord injury were present.

War Injuries. It was, however, World War I which stimulated wider interest in the pathology and mechanism of production of lesions in spinal cord injuries as well as providing abundant material. Full use of this material was made by Gordon Holmes in his classical Goulstonian Lectures (1915) on 'Spinal Injuries of Warfare'. Over 300 cases were encountered clinically, and post-mortem examinations were obtained in about 50 cases, of which the histological changes were studied in a certain number. He found that the lesions were rarely sharply limited or circumscribed and, therefore, could not be compared with those produced experimentally in the laboratory. The cord could be injured directly by a projectile, being either completely or incompletely divided. More commonly it escaped direct damage and was injured by displaced fragments of bone which either compressed or lacerated it. Frequently, however, the cord was not injured directly either by a projectile or by in-driven bony fragments. There were in these cases extreme structural changes attributed to concussion or commotion effects due to the missile striking some portion of the vertebrae and producing severe vibrations. In more than half of the cases examined microscopically, and in those in which only a nakedeye examination was made, large cylindrical cavities were noted in segments adjoining the site of maximal damage, either above, below, or at both levels. A detailed description of similar cavities was given by Buzzard and Greenfield (I92I), who regarded them as being due to serum and oedema fluid formed at the level of the lesion, being forced to track up and down the cord due to the restraining influence of the intact pia mater. Their occurrence in the ventral part of the posterior columns was thought to be due to the comparatively poor blood supply of this area. 
Gunshot wounds of the spinal cord were studied by Collier (I9I6). Four types of lesion were described as a result of these injuries. A direct lesion resulted from the passage of the missile across the spinal canal irrespective of whether it touched the cord or not. Indirect lesions resulted from the in-driving of bone into the spinal cord or from the concussive effect of the shock of high explosives. Secondary lesions resulted from haemorrhage, which could be intramedullary, intrathecal or perithecal, thrombosis, infection or oedema. Remote lesions found anywhere in the spinal cord and including areas of necrosis, sieve-like rarefaction, punctate haemorrhages and oedema were also described. These were particularly prominent in cases of spinal concussion resulting from the bursting of high-explosive shells, without any detectable external wound, lesions of soft tissues or bony fractures. The effect of direct injuries to the cord by bullets or shell fragments were also well described by Roussy and Lhermitte (I9I7-I8). Other reports on spinal cord pathology in soldiers who sustained vertebral injuries by projectiles without the cord receiving a direct wound were made by Claude and Lhermitte (I9I6), Lhermitte (I9I7) and Ferraro (I922). The cases were described as examples of concussion. Clinically, these had total or subtotal transverse lesions while pathologically foci of necrosis, cavitation, acute primary degeneration of nerve fibres and glial proliferation were found. Acute softening of both the brain and the spinal cord without haemorrhage in cases of non-penetrating gunshot wounds caused by impact contusion was described by Cadwalader (1919). The pathology of gunshot wounds of the spinal cord as illustrated by specimens in the War Office Collection was described by Keith and Hall (I919) and Thorburn (1920). A review of World War I spinal cord injuries was made by the Medical Research Council (I924) and by Foerster (1929) based on personal experience of 395 cases. In World War II, the spinal cord lesions seen in 57 patients with gunshot wounds of the spine admitted to an Evacuation Hospital in 1943-44 were described by Pool (1945). A series of I84 cases of acute war wounds of the spinal cord was analysed by Haynes (I946). In volume 'Surgery' of the British History of the Second World War (I953), Guttmann recorded 35I cases from World War II amongst a total of 388 Service injuries of the spinal cord. In discussing the mechanism and pathology of the cord injury, he has drawn particular attention to cases with cord injuries in both transverse and vertical directions, following blunt or penetrating injuries to the spine. Such injuries involving the mid and upper thoracic cord remain permanently flaccid, as a result of longitudinal damage to the lower motor neurone.

The effects of high explosives on the central nervous system was reported by Claude and Lhermitte (I9I5) and Mott (I9I6, I9I8). The latter described a case in which death occurred two days after a soldier had been buried as a result of an explosion. Excavation was effected within five minutes of burial. No gross injuries, fractures or dislocations could be found, but there was diffuse sieve like vacuolation of myelin fibres with swollen axis cylinders in the posterior columns of the lower cervical cord with grey matter contusion involving both anterior and posterior horns on one side at C5. Mairet and Durante (I9I9) and Guillain (I920) believed the medullary lesions were due to the air pressure changes. The effects of blast and concussion as seen in World War II were reported by Fulton (1942). The subject of blast injury has been reviewed extensively by Denny-Brown (I945) and by Clemedsen (1956).

These war-time studies of necessity included only recently injured cases so that the pathological changes seen were those of the acute stages. Elsberg (I9I9), 
however, described the lesions observed in 20 cases during operations for old injuries to the spinal cord resulting from long-standing fractures or wounds of the vertebral column. He divided them into those involving the cord and roots, although they were often combined. The dura may become so thickened that it exerts pressure on the cord like an extramedullary tumour. The arachnoid may become thickened, opaque and adherent to either dura or spinal cord so that irregular cavities filled with cerebrospinal fluid may result in the condition of 'adhesive arachnoiditis'. The spinal cord often showed little macroscopic change, although severe symptoms and loss of function may be present. Hydromyelia or haematomyelia was noted in some cases.

Knife Stab Wounds. Knife stab wounds of the spinal cord are more likely to result in lateral hemisection of the cord producing the syndrome of BrownSéquard (1868) than in any other form of injury. Three such cases had been described by Eve in I85 I, while Staub (1860) recorded a case resulting from a penetrating wound below the occiput and the atlas. Weiss (I877) reported a similar case. Head (I906) pointed out that in knife stab wounds it is most usual for both dorsal columns to be divided, with otherwise a fairly exact hemisection. Gribbon (1876) reported a case of self-inflicted puncture wound of the neck with immediate numbness of the hand and cerebrospinal fluid leak leading to death from meningitis I8 days later. Wagner and Stolper (I898) collected 8I cases from the literature while Petren (I9I0) found 93 cases of which 43 involved cervical segments and the remainder thoracic. The point of the knife may occasionally become broken off and left in the spinal cord (Rodrigues, I897; Owen, 1917). Seven cases of stab wounds of the spinal cord were reported by Rand and Patterson (I929), of which one died I4 days after injury. At autopsy, there was marked haemorrhage into the spinal canal and along the spinal cord. The subject was reviewed by St. John and Rand (I953), while Rosenberg (I957) described I9 patients seen in one hospital over a period of 33 years. The chief pathological features encountered in a series of 130 cases were described by Lipschitz and Block (1962). They considered that the spinal cord could be injured directly, or by interference with its vascular supply or by contre-coup effects.

Further Work on Concussion. Since the classical experiments of Schmaus which were subsequently confirmed by Jakob (1919), several more experimental observations on percussion using different methods have been performed. Thus Stcherbak (1907) employed a special vibrating apparatus while D'Abundo (I9I6) used repeated centrifugalisation of small animals. Allen (I9I4) carried out an experimental study of histopathological changes in the spinal cord due to impact. Marinesco (I9I8) studied experimental concussional lesions in dogs exposed to gun-cotton explosions. Roussy et al. (1920) struck the vertebral column in the thoracic region of guinea-pigs and a rabbit and investigated the damage produced. McVeigh (1923) exerted pressure on the exposed spinal cords of dogs with the tip of the finger. A detailed histological study of the early lesions of experimental concussion of the spinal cord in rabbits was carried out by Ferraro (I927), who administered blows with an iron rod. Lesions were noticeable as early as one hour after trauma. Swelling and deformity of axis cylinders appeared to be the primary lesion. Changes in myelin sheaths were shown by osmic acid reduction within I 2 hours. Neuroglia enlargement was also noted in the first few hours. Lesions 
of Nerve cells were moderate compared with those of the fibres. The cell outline became broken with fragmentation of its prolongations, conglutination of the neurofibrillae, retention and displacement of the nucleolus within the nucleus. These changes occurred within one to four hours, suggesting a primary origin rather than reaction following the axonal lesions. The pathogenesis of these lesions was interpreted as being due to shock of the cerebrospinal fluid transmitted all round the cord and the vibratory action of the tissues. The pathological changes described by these investigators in experimental spinal concussion were found not only in the regions subjected to blows, but also remote from the site of the original trauma. Similar findings have been reported in man by Hellbach (1909), Henneberg (I915), Davison (1960) and others.

Hassin (1923) reviewed the subject of concussion of the spinal cord and reported a case with the clinical picture of amyotrophic lateral sclerosis. He also recorded the histopathology of spinal contusion (I925).

Davison and Keschner (1933) attributed to concussion the foci of necrosis found at varying distances below the primary lesion in cases of compression fracture. Baldwin (1934), in describing two cases that survived 28 and I4 days after injury, reported primary and secondary degeneration of nerve fibres, foci of softening and destruction of ventral horn cells as manifestations of concussion.

Marburg (1936) observed four cases of spinal concussion in which the neurological signs disappeared completely. In one instance the symptoms of a complete transverse lesion cleared up after several days. He believed that cases with demonstrable pathological changes in the cord should not be called concussion but this should be reserved for changes which clear up shortly afterwards through a reversibility of reaction.

Knight (1940) believed that uncomplicated concussion of the cord would resolve completely with time, often within 24 hours or sometimes delayed one week or more. Pool (I945) suggested a period as long as 5 to 20 days. If more severe damage than concussion was present the signs of this became manifest as concussion passed off. Walker et al. (1944) regarded cerebral concussion as a depolarisation of nerve cell membranes with resulting massive discharge. Groat et al. (1945) critically reviewed the use of the term concussion. In an experimental study of spinal concussion in the cat, they concluded that uncomplicated concussion of the cord is a complete functional block at the level of the application of force. They found changes in nerve cells, especially the interneurones and in long ascending and descending fibre tracts. If other morphological changes were present such as haemorrhage, contusion or laceration which superimposed functional alterations upon those of concussion, the injury should not be reported as concussion but as concussion plus complicating injury. Although the temporary derangement of segmental neurones and reflex arcs, the so-called 'commotio spinalis', was admitted as a possible mechanism of concussion, Scarff (I960) suggested the probability that in those cases where loss of function was prolonged for many days, oedema of the cord might be a concomitant contributing factor. He stressed the frequency of oedema in every major spinal injury and in causing block of the spinal subarachnoid space during the first 48 to 72 hours after trauma.

Compression and Contusion. Thompson (I923) crushed the spinal cord of dogs with the finger or handle of a scalpel, producing cone shaped areas of destruction above and below the lesion when the crush was complete similar to the 
cone-shaped lesions described by Thorburn and Richardson (I9I9) in gunshot wounds of the spinal cord. Thompson also described in the same article the pathological changes occurring in the spinal cord following fracture dislocation of the vertebra. Thirteen cases, in which death ensued instantaneously in two cases, after a few days in three, and several weeks or months in the remainder, were described.

Davis and Voris (1930) gave the detailed histology of the spinal cord of a 38-year-old man who survived 17 days after sustaining a compression fracture of the body of the sixth cervical vertebra. The dura around C6 was discoloured by blood from ruptured vessels of the dura, whilst the sixth cervical segment showed haemorrhage in the grey matter on the left side with petechiae on the right side and in the dorsal and lateral columns. The lateral columns in the region of the corticospinal and rubrospinal tracts were partially destroyed at C6-7 and this was not entirely due to haemorrhage. That these haemorrhagic lesions, especially when spread over a few segments, might coalesce to form a cavity was mentioned by Cohen (I93I), who reviewed the literature on the problem of the late appearance of symptoms of haematomyelia, where periods ranging from a few hours to six months might elapse between the time of injury and the onset of symptoms. Traumatic haematomyelia was also described by Binet and Mosinger (1928) and Bolten (1934).

Jefferson (1928), in opening a discussion on spinal injuries, noted the rarity of cord compression. Riddoch (1928) followed with a description of the pathological changes which he subdivided into haemorrhagic, neural and oedematous. Jefferson (1936) recorded the pathological effects in 75 cases of cord or root injury. The cord was rarely compressed by bone fragments. When haemorrhage occurred it was usually central into well-vascularised grey matter. He thought that the main damage was due to local neural disruption with rupture of myelin sheaths, fracture of axons and contusion of nerve cells rather than haematomyelia. In I 940 he again emphasised the relative freedom of cord injuries from gross haemorrhage, stressing the severe distortion of the internal pattern with fissuring of cord substance. He pointed out that the central mass of the cord was not the area most damaged and that the subpial region could be torn radially by the drag of pial penetrating fibres.

Reverting to the lower end of the spine, the pathological effects of contusion of the cauda equina were reviewed by Hassin (I944). Most previous observations had been clinical or, if pathological, restricted to gross changes such as lacerations, haemorrhages, adhesions or scars, without microscopy. Haemorrhage was seen in both anterior and posterior roots. There was pallor of staining and accumulation of basophil-metachromatic substances in granular form. Swelling of the epineurium and perineurium, disintegration of myelin sheaths, changes in axons which become swollen, granular and homogeneous or vacuolated and fragmented into balls were observed by Hartmann (I900), Kirchgässer (I897), Claude and Lhermitte (1915), Marburg (1936) and Scheinker (1942). The importance of 'root escape' in thoraco-lumbar fractures where the cord receives irrecoverable damage has been stressed by Holdsworth and Hardy (1953) and Holdsworth (1954).

Relationship to Bone Injury. Walshe and Ross (1936) pointed out that fracture or fracture dislocation of the cervical spine may be sustained without any cord damage or there may be complete quadriplegia with priapism and retention. Between these two extremes the cord may be slightly damaged, due to either 
momentary nipping when the cervical vertebra is displaced or due to momentary stretching over the posterior aspect of the vertebral bodies when the head is forcibly flexed. Although injury to the bone may occur without evident injury to cord or nervous elements and damage to the neural elements may be present without demonstrable bony injury, more often there is concurrent injury to both elements (Scarff, 1937). The level of the two may not coincide, as Crooks and Birkett (1944) found that the cord injury was usually at a higher segment than the spinous injury, suggesting the importance of traction in the mechanism.

The problem of paraplegia occurring after an injury with normal X-ray findings was raised by Plewes (1938), who reported a case. He suggested that it was due to an acute retropulsion of an intervertebral disc in hyperflexion with immediate reduction. Cramer and McGowen (1944) also accepted this hydraulic ram-like action of the nucleus pulposus rather than the recoil by reflex contraction of antagonistic muscles of a dislocated vertebral body. Barnes (I948, I95 I) pointed out the lack of correlation between the degree of initial displacement and the severity of the spinal cord lesion. He considered that pre-existing rigidity in an osteoarthritic neck was an important feature which resulted in snapping of the spine like a dry stick concentrating angulation at one level instead of dispersing it over several segments as in a normal flexible spine. He believed that a cervical cord injury resulted from a combination of two factors, one being the pressure on the dorsal surface of the cord by the dislocated neural arches or bulging interlaminar ligament, and the other being the coincident compression of the ventral surface of the cord by retropulsed disc material or adjacent osteophyte. Taylor and Blackwood (1948) were sceptical of the idea that these cases were due to posterior displacement of nucleus pulposus, considering it most unlikely that the inelastic annulus and the posterior longitudinal ligament should stretch sufficiently to allow contusion of the cord without actual rupture. They believed these cases were due to hyperextension injuries. The mechanism by which profound injuries to the cervical spinal cord may occur in hyperextension without fracture or dislocation was discussed by Alexander et al. (1958) and the importance of the sagittal diameter of the spinal canal measured radiographically in relation to these injuries was emphasised. The possible causes of not demonstrating cervical spinal damage on X-ray in cases of cervical cord injury were listed by Cook (1959). Inadequate radiography, pre-existing cervical spondylosis or rupture of the anterior longitudinal ligament allowing extreme extension of the cervical spine provided some of the explanations.

In review of paraplegia in cervical spine injuries, Barnes (1948) reported an incidence of approximately two-thirds of the patients having undergone a flexion force and one-third hyperextension. Examples of hyperextension injury were reported by Kaplan (I953), Berkin and Hirson (1954) and Rogers (1957), although one of the earliest cases with rupture of the anterior common ligament but without fracture had been described Ioo years previously (Butcher, I853). Miller and Schultz (1958) classified hyperextension injuries into three types. In type I, where the injury was associated with an arthritic spine the prognosis was reasonably good, but in type 2 where the anterior longitudinal ligament was ruptured and in type 3 where there was dislocation in addition, the prognosis was poor. The forces involved in type 2 and 3 injuries were much greater and sometimes a small piece of bone might be avulsed from the anterior part of the cervical vertebral body. That the anterior longitudinal ligament has no elasticity or stretch but has a high 
breaking strength, averaging 337 pounds in autopsy specimens, was shown by Davis (1943). Cases of haematomyelia associated with hyperextension injuries of the neck were reported by Nattrass (1944) and Robson (I956).

Types of Cord Damage. A series of IOI cases of cervical cord injury, of which 46 were fatal, was studied by Munro (I943a). Autopsy was carried out in I3 of these and pathological changes in the spinal cord consisted of transection, contusion, compression and haematomyelia. In a study of 40 cases of thoracic and lumbo-sacral cord injuries made by the same author (1943b) similar findings were encountered in I I of the 23 fatalities in which autopsy had been performed.

Davison (1945) gave a most complete and masterly review of the whole range of pathological changes encountered in the spinal cord as a result of trauma of different varieties. The injuries of the spinal cord may result from fractures and dislocations, direct or indirect, blows to the vertebral column such as falls, stabs, gunshot wounds, bomb and shell explosions, violent muscular strains and sudden changes in atmospheric pressure as in caisson disease. The pathological changes in the cord depended on the type, extent and mechanism of the injury to the vertebrae, cord, membranes and nerve roots. The essential pathological picture was that of concussion, contusion or compression, each alone or in combination. Lacerations, haematorachis and haematomyelia might also occur. He regarded concussion as an undoubted pathological process, rather than a functional disturbance, in which the histopathology was not uniform but varied according to the intensity of the injury and the duration of the lesions. The occurrence of cylindrical cavities in the dorsal horns or in the posterior columns near the grey matter, which have been found by most experimenters, was noted.

A series of detailed studies of the histological changes seen in the human spinal cord after fatal injury was made by Bailey (I943-6I). Seven cases with survival periods ranging from 7 hours to 60 days provided the material for these investigations. The nuclear changes in the anterior horn cells showed progressive degeneration with the longer periods of survival (1943). The alterations in nerve cells (I959) and in the nerve fibres (I960) were also studied, while glial cell changes (I96I) were described most recently.

In a discussion on injuries of the spinal cord, Freeman (I954) pointed out that, although these can be classified into concussion, contusion and laceration, they are frequently associated, while in the completely severed cord there is a greater element of mesenchymal proliferation, repair and scarring. Incomplete injury of the spinal cord usually resulted in the Brown-Séquard phenomenon. A series of 27 such cases was studied by Taylor and Gleave (1957). The damage was caused by a gunshot wound in 16 of these cases and a fracture or fracture dislocation of the cervical spine was present in nine. No definite knowledge of the nature of the pathological damage to the cord was established because only one patient died, a year after injury, and the cord was not examined.

The causes of the immediate and the late onset of paraplegia in injuries of the cervical spine were recently reviewed by Barnes (I96I). The immediate onset of paraplegia was caused by direct contusion of the cord. Compression had no part in its development and probably little influence on its persistence. The contusion was caused by compression fracture, dislocations and hyperextension injuries. The mechanisms of these bony injuries were described by Roaf (I960). The late onset was due to compression by bony spurs or slowly developing deformities. 
Vascular Lesions. The characteristic morphology of the vascular alterations in the central nervous system following trauma was reported by Scheinker and Evans (1945). Scheinker (1944) emphasised these vascular changes, dividing them into vasoparalysis, general or localised, associated with increased permeability of the wall, followed by degeneration and necrosis of vessel walls. The end-result in cases with long survival was a homogenisation, loss of stainability and thinning out and atrophy of the entire vessel wall. These vessel changes, by interfering with the blood supply, produced oedema, softening, liquefication and necrosis of the nervous tissue. This view that the primary damage was to blood vessels with secondary changes in the parenchyma had been previously advocated by Hartmann (I900) and by Marburg and Ranzi (I9I8-I9). It is in marked contrast with that of Davison, who believed the injury could produce changes in the parenchyma primarily, and of Hassin (I923), who regarded the haemorrhages in concussion as concomitant phenomena and not essential or primary factors, though they may dominate the pathological picture. However, fibrin thrombi have been observed in blood vessels in meninges and parenchyma (Osnato \& Giliberti, I927), suggesting a primary involvement.

Major vessel thrombosis as a result of relatively trivial injuries has been described. Tempory luxations of the vertebrae, especially in the cervical region, may follow sprains which accompany yawning or sudden stretching of the arms, with possible compression of the spinal cord vessels, especially the anterior spinal artery (Spiller, I909; Grinker \& Guy, I927; Ornstein, I93I; Zeitlin \& Lichtenstein, I936). Massive and extensive softening of the cord without any observable vessel thrombosis has also been recorded after similar trivial strains (Bassoe \& Hassin, I92 I; Keschner \& Davison, I933; Stone \& Roback, 1937; Kaplan, 1953).

Although delayed myelopathy following atlanto-axial dislocations with displaced odontoid process had been described in the earlier literature, Bachs et al. (I955) found only nine reported cases, including one of their own, and added a second case. They concluded that compression, angulation and stretching of the spinal cord led to the delayed myelopathy, in the pathogenesis of which blood vessel changes and meningeal hypertrophy were important factors. Stratford (I957) described the autopsy findings in a similar case where the injury occurred 25 years before the onset of symptoms. The pia arachnoid was thickened and the cervical cord was flattened with loss of substance. Above the site of cord compression there was bilateral degeneration of the spinothalamic tracts and posterior columns while below the crossed pyramidal tracts showed demyelination.

Role of Dentate Ligaments. The importance of the dentate ligaments in chronic anterior cord compression by a posteriorly protuded cervical nucleus pulposus was emphasised by Kahn (1947). Owing to the anchoring effect on each side by the ligamenta denticulata, the anterior cord compression would produce mechanical stresses resulting in symptoms. These ligaments prevented the cord from being crushed against the bony lamina and traumatic rupture of the dentate ligaments did not occur except when there had been complete pulping of the cord (Kahn, I959). Bucy et al. (I948) and Schneider (I95 I, I955) reported examples of cervical spine injuries resulting in a prolapsed disc with symptoms of cord involvement accentuated by the effect of the dentate ligaments. Schneider and Kahn (1956) pointed out the significance of acute flexion injuries of the cervical 
spine producing displacement backwards of the posterior inferior margins of the body of the vertebra which, with the dentate ligaments, had a similar effect on the cord. The importance of the role of the ligamenta denticulata in cervical disc lesions has been questioned by Logue (1957) and Bradshaw (I957). The tethering action of nerve roots and rootlets was emphasised by O'Connell (I956). Taylor (I95I) stressed the importance of the forward bulging of the ligamentum flavum compressing the cord in hyperextension injuries. Payne and Spillane (1957) demonstrated in hyperextension of the neck the appearance of ridges over the intervertebral discs and bulging of the ligamentum flavum which may further constrict the already limited spinal canal. The indentations produced anteriorly and posteriorly in the cord by this mechanism have been aptly referred to by Robson (I956) as 'molding' of the spinal cord.

Compression by Prolapsed Intervertebral Disc. Although trauma to the spine can result in prolapse of an intervertebral disc which can damage either nerve roots or the spinal cord, relatively few reports have appeared in the literature concerning the pathology of the spinal cord produced by prolapsed intervertebral discs (Middleton \& Teacher, I9I I; Fleiss \& Ingham, I943; Brook, I944; Browder \& Watson, 1945; Brain et al. 1952; Bedford et al. 1952; Logue, 1952). Mair and Druckman (1953) found the area of involvement, except for the sparing of the anterior columns, to be in the field of supply of the anterior spinal artery as postulated by Tureen (1938).

In order to elucidate the effects of compression on the spinal cord as produced by prolapsed intervertebral discs, other spinal tumours or fracture dislocations, the problem was submitted to experimental analysis in dogs by inserting an inflatable rubber balloon extradurally within the spinal canal by Tarlov et al. (1953, I954). Previously Allen (I9I I, I9I4) and Freeman and Wright (I953) had attempted to ascertain how long a spinal cord may be compressed without precluding functional recovery. Resulting from the animal experiments, the conclusions reached by Tarlov (1957) were that functional recovery after acute extradural compression of the spinal cord depends upon the magnitude and duration of the compressive force. With large compressive forces recovery of function occurred when the compression was released within one to five minutes, but did not occur when the compression was applied for longer periods. The cause of these irreversible changes was cord destruction at the site of compression. With minimal compressive forces used to produce paralysis and complete sensory loss, recovery occurred after periods of compression up to two hours. Mechanical deformation of tissue rather than anoxia due to ischaemia was regarded as the cause of spinal compression paralysis, although in the non-recoverable cases extensive cord destruction with tissue vacuolation and cavitation at the compression site and extending above and below was found. Occasionally there was massive haemorrhage either alone or together with softening. Olsson (1958) found similar results were produced by cervical disc protusions, as a slow-growing large protusion may be accompanied by slight symptoms whereas a sudden protusion could result in severe trauma to the cord with haemorrhage.

Whiplash Injuries. Whiplash injuries were first described by Gay and Abbott (1953) and have received great prominence in recent literature. Thus Gotten (1956) was able to review Ioo cases. They are, in effect, only sudden 
hyperextension injuries and usually occur as a result $\mathrm{O}_{1}$ a halted vehicle being struck from behind.

Birth Injuries. Birth injury to the spinal cord was first described by Kennedy (I836) and later by Parrot (I870). Subsequently further reports were made by Ruge (I875), Spencer (I89I), Stoltzenberg (I9I I) and Pierson (I923). Classic work on this subject was done by Crothers (1923), Ford (1925) and Crothers and Putnam (1927). The subject was reviewed by Stern and Rand (1959). They were able to collect 53 well-documented examples. The cervicothoracic cord was the commonest site of injury, which might be complete or partial. Forceful breech extraction was the commonest cause although it occasionally occurred with cephalic presentations. Six cases with subsequent follow up were recently reported by Leventhal (I960).

Repair. The pathological findings in cases surviving many months after sustaining a traumatic paraplegia were described by Greenfield et al. (1958). At the level of an old fracture dislocation there was dense fibrous scar tissue formed by fusion and thickening of the periosteum with the dura mater. The leptomeninges were frequently adherent to the scar with partial obliteration of the subarachnoid space, especially on one side. The cord became thinned and sclerotic and in severe cases was completely demyelinated with fibrous gliosis or was converted into a fibrous band. The shrunken cord, often deep yellow in colour due to staining with haemosiderin, might contain one or more cysts. Cysts might also be present in the thickened pia arachnoid in the adhesive arachnoiditis at the site of old injury resulting in a spinal block. If the dura had been ruptured or opened during laminectomy, the arachnoid cysts could become extradural, as reported by Swanson and Fincher (1947).

Regeneration. Although it has long been accepted that regeneration in the human central nervous system does not occur, recently this has been questioned (Windle, I955). The regenerative capacity of the central part of the posterior nerve roots has been frequently noted in spinal cord injury. The regenerated fibres entering the cord are covered with Schwann cells and are well myelinated. Thus Minor (1904) recognised bundles of myelinated fibres in the scar of the cord of patients with old traumatic lesions. Marinesco and Minea (I906) examined two cases of spinal cord compression due to dislocation of the first lumbar vertebra and found regenerated fibres accompanying blood vessels in the anterior median fissure, leptomeninges round the cord, in the posterior roots, in the scar and nearby grey matter. Henneberg (1907) found regenerating fibres in the leptomeninges covering the dorsal columns and extending into the cord in total transverse lesions of the cord. He believed they originated from posterior nerve roots. A similar origin was attributed by Klaue (1949) to the fibres seen in the scar of a grenade wound of the cord.

The long-held belief that regeneration of axons of the spinal cord did not occur has been amply disproven by work on experimental animals. Thus regeneration within the central nervous sustem of amphibia has been demonstrated by Hooker (I9I5, I9I7, I925), Lorente de Nó (I92I), McCreight (I924), Piatt (I955) and Stephens (1959). In mammals after experimental transection of the cord, regeneration was shown by Dentan (1873), Eichhorst and Naunyn (1874), Stroebe 
(I894), Nageotte (I899) and Cajal (I928). This regenerative capacity was much greater in embryonic or newborn animals (Gerard \& Grinker, I93I; Nicholas \& Rudnick, I933). Evidence of intraspinal sprouting of dorsal root axons with the development of new collaterals and preterminals following partial denervation of the spinal cord was shown in the cat by Liu and Chambers (1958). Regenerating fibres from both the cord tracts and spinal roots were demonstrated in the rat after cord transection by Sugar and Gerard (1940). Invasion of the spinal cord by axons from ventral nerve roots was confirmed by Wohlfart (I96I).

Apart from traumatic cases, aberrant regenerating fibres are commonly seen in syringomyelia. Druckman and Mair (1953) found them in spinal cord compression by prolapsed intervertebral discs and by myeloma of the spinal column. They frequently lie adjacent to blood vessels as isolated fibres or large bundles. They were thought to have arisen from the long white tracts, from decussating fibres of the anterior white commissure, and from axons of nerve cells in the grey matter as well as from nerve roots. This power of outgrowth of peripheral nerve fibres can persist for a very long time and was demonstrated as long as 3,I64 days after injury in a human case reported by Bowden and Gutmann (1944). The present position and future possibilities of regeneration in the central nervous system have been reviewed recently by Windle (I962).

\section{DISCUSSION}

From this historical review of the literature, the development of knowledge concerning the pathology of spinal cord injuries can be traced and the various gaps in our information or where confusion exists can be outlined. By this method topics meriting further investigation become apparent and these will be dealt with in subsequent papers.

Of the numerous aspects only four will be considered:

I. Concussion. This term has been used in numerous ways, each with a different meaning. Thus the functional disturbance of the spinal cord following injury and usually resulting in recovery within a period varying from a few hours to a few weeks has been described as concussion. It has also been applied to the temporary or permanent loss of spinal cord function produced by direct or indirect blows to the spine as in falls, jolts, bullets, skull fractures, and blast injuries from explosions. Usually the vertebrae remain intact. Often there is disturbance of function in parts of the cord distal from the original site of injury and it is to this aspect that the term concussion has been applied.

A further use of concussion is in the state of affairs which exists when after an injury without any evidence of fracture or displacement of the spine there is cord damage shown either clinically or pathologically, or by both means. More or less complete paraplegia may be found following blows on the vertebral column or falls on the head, buttocks or feet in the absence of bony injury. The application of the term 'spinal cord concussion' to this is justified on the grounds that we have no other convenient short term to describe the mechanism.

Thus spinal concussion has been used to imply five different aspects of trauma. These include functional disturbance without microscopic change, mildness, reversibility, remoteness from the original site of injury and cord damage in the absence of any fracture or dislocation of the vertebrae. Although histological 
changes which may be absent or minimal are accepted under the first three interpretations of concussion, much grosser lesions are acceptable if either of the last two definitions are employed. A detailed examination of the spinal cord utilising modern histological techniques in a large series of paraplegics dying after varying periods of time after injury of differing degrees of severity and the subsequent. clinicopathological correlation would clarify the histological changes accompanying each of the several features included in 'concussion'.

2. Vascular Disturbances. Bleeding into the cord is a very frequent accompaniment of injury and is most often seen in the grey matter. The mechanism of this form of contusion appears to be acute compression of the cord by the fractured or dislocated vertebrae. If the degree and duration of compression are greater, the effects on the cord and especially on its blood supply will be more and thrombosis more likely to occur. The relative importance of these two types of vascular disturbance in the role of production of cystic cavitation of the cord seen in old traumatic cases warrants further investigation.

3. Ligamentum Denticulatum Attachment. The importance of these structures in producing lesions in the cord due to their tethering effect is controversial. The practical implications of this argument are significant as benefit may result from the surgical division of these structures in the post-traumatic period. Detailed study of the cord after varying periods of survival should provide an answer.

4. Repair and Regeneration. Although anatomical regeneration at the site of complete severance of the spinal cord has been observed in adult rats, cats, dogs, monkeys and man, and there is ample evidence that the regenerated nerve fibres are capable of conducting nerve impulses in the cat, there is little evidence as yet that true physiological recovery, either motor or sensory, has been obtained in mammals. Only by a careful and thorough neurological examination carried out at regular intervals over a long period in a surviving paraplegic with particular attention paid to any changes in the sensation or motor function and the subsequent histological examination and correlation will provide an answer as to whether the regenerated fibres can provide therapeutic possibilities in man.

\section{SUMMARY}

A historical review of the development of knowledge of the neuropathology of injury to the spinal cord has been undertaken.

From a critical appraisal of this information attention has been focused on several of the gaps in our understanding of the subject which warrant further investigation.

\section{RÉSUMÉ}

Cette étude porte sur le développement des connaissances neuro-pathologiques de l'atteinte traumatique de la moëlle épinière.

De cette étude il ressort que certaines lacunes existent conçernant ce sujet demandant de futures recherches. 


\section{ZUSAMMENFASSUNG}

Der Verfasser gibt eine geschichtliche Übersicht über die Entwicklung unserer Kenntnis der Neuropathologie der Rückenmarksverletzung.

Kritische Beurteilung lenkt unsere Aufmerksamkeit auf die Lücken in unserem Wissen, die weitere Untersuchungen notwendig machen.

\section{REFERENCES}

Abercrombie J. (1928). Pathological and Practical Researches on Diseases of the Brain and Spinal Cord. Section 9 'Concussion of the Spinal Cord', p. 375. Edinburgh: Waugh and Innes.

Alexander Jr., E., Davis Jr., C. H., \& Field, C. H. (1958). Arch. Neurol. (Chic.), 79, I 46. Allen, A. R. (I9I I). F. Amer. med. Ass. 57, 878.

Allen, A. R. (I9I4). F. nerv. ment. Dis. 4I, I4I.

Bachs, A., Barraquer-Bordas, L., BarraQuer-Ferré, L., CANadell, J. M., \& Modolell, A. (1955). Brain, 78, 537.

Bailey, F. W. (I943). Bull. Los Angeles neurol. Soc. 8, I29.

Bailey, F. W. (1959). Bull. Los Angeles neurol. Soc. 24, 204.

Bailey, F. W. (1960). Bull. Los Angeles neurol. Soc. 25, I47.

Bailey, F. W. (I96I). Bull. Los Angeles neurol. Soc. 26, 32, I72.

Bailey, P. (1900). Med. Rec. 57, 573.

Baldwin, R. S. (1934). Arch. Neurol. (Chic.), 32, 493.

BARNes, R. (1948). F. Bone ft. Surg. 30B, 234.

BARNES, R. (I95I). F. Bone ft. Surg. 33B, 494.

Barnes, R. (196I). Proc. R. Soc. Med. 54, 365.

Bassoe, P., \& Hassin, G. B. (I921). Arch. Neurol. (Chic.), 6, 32.

BEDFord, P. D., Bosanquet, F. D., \& Russell, W. R. (1952). Lancet, 2, 55.

BeLL, C. (I817). Surgical Observations. Injury of the Spinal Marrow from a Hurt on the Spine, vol. I, p. I 52. London: Longman.

Berkin, C. R., \& Hirson, C. (I954). F. Bone ft. Surg. 36B, 57.

Binet, L., \& Mosinger, M. (I928). Rev. neurol. I, I67.

Boeckel, J. and A. (I9I I). Rev. Chir. (Paris), 43, 649.

Bolten, G. C. (1934). Mschr. Psychiat. Neurol. 78, 274.

Bowden, R. E. M., \& Gutmann, E. (1944). Brain, 67, 273.

BRADSHAW, P. (1957). Quart. F. Med. 26, I77.

BRAIN, W. R., NoRTHFIELD, D., \& Wilkinson, M. (I952). Brain, 75, 187.

Brooke, W. S. (1944). F. Amer. med. Ass. 125, I I 7.

BROWDER, J., \& WATSON, R. (1945). N.Y. St. F. Med. 45, 730.

BROWN-SÉQUARD, C. E. (I868). Lancet, 2, 593, 659, 755 and $82 \mathrm{I}$.

Bucy, P. C., Heimburger, R. F., \& Oberhill, H. R. (I948). F. Neurosurg. 5, 47 I.

Butcher, R. G. H. (1953). Dublin F. med. Sci. 15, 383.

Buzzard, E. F. \& Greenfield, J. G. (I92I). Pathology of the Nervous System, p. 88. London: Constable.

Cadwalader, W. B. (I919). Arch. Neurol. (Chic.), 2, 244.

Cajal, S. R. Y. (I928). Degeneration and Regeneration of the Nervous System. Trans. May, R. M., vol. 2, pp. 558-582. London: Oxford University Press.

Casamajor, L. (I921). N.Y. State f. Med. 21, 99.

Celsus, A. C. (I 478). De Medicina, lib. viii. fol. Florent. Nicolaus Laurentii. 3 vols. Trans. Spencer, W. G., Cambridge I 935-8. Harvard Univ. Press; and London: Wm. Heinemann.

Clark, F. Le Gros (I892). Lancet, I, I078.

Claude, H., \& Lhermitte, J. (I9I 5). Ann. Med. 2, 479.

Claude, H., \& Lhermitte, J. (I9I6). Rev. Med. (Paris), 35, 535.

Clemedsen, C.-J. (1956). Physiol. Rev. 36, 336.

Clevenger, S. V. (1889). Spinal Concussion. Philadelphia: Davis.

Clutton (I89I). Lancet, 2, 928.

Cohen, E. (I93I). Arch. Psychiat. Nervenkr. 95, 439.

Collier, J. (I9I6). Lancet, I, 7I I. 
Cook, J. B. (1959). Proc. R. Soc. Med. 52, 799.

COOPER, A. (1822). A Treatise on Dislocations and Fractures of the foints, p. 557. London: Lnogman.

Corner, E. M. (1907). Ann. Surg. 45, 9.

Cramer, F., \& MCGowan, F. J. (1944). Surg. Gynec. Obstet. 79, 5 I6.

Crooks, F., \& Birkett, A. N. (I944). Brit. F. Surg. 31, 252.

Crothers, B. (1923). Amer. F. med. Sci. 165, 94.

Crothers, B., \& Putnam, M. (1927). Medicine, 6, 4 I.

D’Abundo, G. (I9I6). Riv. ital. Neuropat. 9, I45.

Davis, A. G. (1943). Arch. Surg. 46, 619.

Davis, G. G., \& Voris, H. C. (1930). Arch. Surg. 20, I45.

Davison, C. (1945). Res. Publ. Ass. Nerv. ment. Dis. 24, I5I.

Davison, C. (1960). Injuries of the Brain and Spinal Cord and their Coverings, p. 498. Ed. Brock, S. London: Cassell.

Davison, C., Keschner, M. (I933). Arch. Neurol. (Chic.), 30, 326.

DenNy-Brown, D. (1945). Physiol. Rev. 25, 296.

DENTAN, P. (1873). Quelques recherches sur la régenération fonctionelle et anatomique de la moëlle épiniere, pp. 44. Diss. Inaug. C. J. Wyss, Berns.

DruckMan, R., \& MAIR, W. G. P. (I953). Brain, 76, 448.

Duménil, L., \& Petel (I885). Arch. Neurol. (Paris), 9, I.

Eichiorst, H., \& Naunyn, B. (I874). Arch. exp. Path. Pharmak. 2, 225.

Elliott, G. R., \& SACHS, E. (I9I2). Ann. Surg. 56, 876.

ElsBerg., C. A. (I9I9). Ann. Surg. 69, 239.

ERICHSEN, J. E. (I882). Concussion of the Spine. 2nd Ed. London: Longman.

Eve, P. F. (185I). New Orleans med. surg. F. Ior, Cases I3, I4, and I5.

FERRARO, A. (1922). Cervello, I, 361.

FERraRo, A. (1927). Arch. Neurol. (Chic), 18, 357.

FICKLER, A. (I905). Dtsch. Z. Nervenheilk. 29, I.

Fleiss, A. N., \& Ingham, H. (1943). F. Amer. med. Ass. 123, 759.

FoERSTER, O. (I929). Handbuck der Neurologie. Ergänzungsband. Berlin: Springer.

FORD, F. R. (1925). Arch. Neurol. (Chic.), 14, 742.

FrEEMAN, L. W. (1954). Surg. Clin. N. Amer. 34, I I3I.

FreEMAN, L. W., \& WRIGHT, T. W. (1953). Ann. Surg. 137, 433.

Fulton, J. F. (I942). New. Engl. F. Med. 226, I.

Gay, J. R., \& Abвотt, K. H. (1953). F. Amer. med. Ass. 152, I698.

Gerard, R. W., \& Grinker, R. R. (I93I). Arch. Neurol. (Chic.), 26, 469.

Gotten, N. (1956). F. Amer. med. Ass. I62, 865.

Greenfield, J. G., Blackwood, W., McMenemey, W. H., Meyer, A., \& Norman, R. M. (1958). Neuropathology, Chap. 6, p. 427. London: Edward Arnold.

GribBoN, G. C. (I876). Lancet, 2, 457.

Grinker, R. R., \& GuY, C. C. (I927). F. Amer. med. Ass. 88, i I40.

Groat, R. A., Rambach Jr., W. A., \& WindLe, W. F. (I945). Surg. Gynec. Obstet. 81, 63.

Guillain, G. (1920). Travaux neurologiques de guerre, p. 307. Paris: Masson.

Gussenbauer, C. (1893). Prog. med. Wschr. 18, 485, 496.

GutTMANN L. (1953). British History of the Second World War, Vol. Surgery. London: Her Majesty's Stationery Office.

Hartmann, F. (1900). F. Psychiat. Neurol. 19, 380.

Hassin, G. B. (1923). Arch. Neurol. (Chic.), 10, 194.

Hassin, G. B. (1925). Arch. Neurol. (Chic.), 13, 369.

Hassin, G. B. (1944). F. Neuropath. exp. Neurol. 3, 172

Haynes, W. G. (1946). Amer. F. Surg. 72, 424.

HeAd, H., \& Thompson, T. (I906). Brain, 29, 537.

Hellbach, H. (1909). Dtsch. Z. Nervenheilk. 37, 22 I.

HENNEBERG, R. (1907). Charité-Ann. 3I, I6I.

HENNEBERG, R. (I9I 5). Berlin klin. Wschr. 52, 859.

HippocRATES: The Genuine Works of Hippocrates (I849). Trans. Adams, F., 2 Vols. London: Sydenham Society.

Holdsworth, F. W. (1954). Ann. R. Coll. Surg. Engl. 15, 281.

Holdsworth, F. W., \& Hardy, A. (I953). F. Bone. Ft. Surg. 35B, 540.

Holmes, G. (I9I5). Brit. med. F. 2, 769 . 
HoOKer, D. (I9I5). F. comp. Neurol. 25, 469.

HoOKer, D. (I9I7). F. comp. Neurol. 27, 42 I.

HoOKer, D. (1925). F. comp. Neurol. 38, 3 I5.

Jakob, A. (I919). Z. ges. Neurol. Psychiat. 51, 297.

JefFerson, G. (I920). Brit. F. Surg. 7, 407.

Jefferson, G. (1928). Proc. R. Soc. Med. $21,625$.

JEFFERSON, G. (I936). Brit. med. F. 2 , I I 25.

Jefferson, G. (I940). Proc. R. Soc. Med. 33, 657.

KaHN, E. A. (1947). F. Neurosurg. 4, I9I.

Kahn, E. A. (I959). F. Bone ft. Surg. 4IA, 6.

Kaplan, C. J. (I953). F. Bone ft. Surg. 35B, 97.

Keith, A., \& Hall, M. E. (I9I9). Brit. Э. Surg. 7, 67.

KENNEDY, E. (1836). Dublin f. med. Sci. p. 4I9.

Keschner, M., \& Davison, C. (I933). Arch. Neurol. (Chic.), 29, 702.

KIRCHGäsSER, G. (I897). Dtsch. Z. Nervenheilk. 2, 400.

KIRCHGäsSER, G. (I899). Dtsch. Z. Nervenheilk. 13, 422.

Klaue, R. (I949). Wien Z. Nervenheilk. 2, 488.

KNIGHT, G. (I940). War Wounds and Injuries. p. I74. Ed. Fletcher E., \& Raven, R. V. Baltimore: Williams and Wilkens.

Kocher, T. (I896). Mitt. Grenzgeb. Med. Chir. I, 48I.

Leventhal, H. R. (I960). F. Pediat. 56, 447.

Lhermitte, J. (I9I 5). Bull. et mém. de la Soc. Méd. d Hôp. 39, 680.

Lhermitte, J. (I9I7). Ann. Méd. 4, 295.

LipsCHITZ, R., \& BLOCK, J. (I962). Lancet, 2, I69.

LiU, C.-N., \& Chambers, W. W. (1958). Arch. Neurol. (Chic.), 79, 46.

Logue, V. (1952). F. Neurol. Neurosurg. Psychiat. 15, 227.

Logue, V. (I957). Modern Trends in Neurology (2nd Series). p. 259. Ed. Williams, D. London: Butterworth.

Lorente De Nó, R. (1921). Trab. Lab. Invest. biol. Univ. Madr. 19, I47.

MacDougall, J. A. (I892). Lancet, I, 863.

Mair, W. G. P., \& Druckman, R. (I953). Brain, 76, 70.

Mairet, A., \& Durante, G. (I9I9). Rev. neurol. 26, 97.

MARBURG, O. (1936). Rückenmark und Gehirn. I. Die traumatischen Erkrankungen des Riickenmarks. Bumke und Foerster's Handbuch der Neurologie. p. IoI. Berlin: Springer.

Marburg, O., \& Ranzi, E. (I9I8-I9). Arch. klin. Chir. III, 7 I.

Marinesco, G. (I9I8). Rev. neurol. 34, 329.

Marinesco, G., \& Minea, J. (I906). Nouv. Iconog. Salpêt. 19, 4 I7.

Maty, M. (1767). Med. Obs. Soc. Phys. London, 3, 257.

Mayo, H. (1836). Outline of Human Pathology. The Spinal Cord. Chap. 5, p. I53. London: Renshaw.

McCreight, J. (I924). Anat. Rec. 27, 38.

McVeigh, J. F. (I923). Arch. Surg. 7, 573.

Medical Research Council, Great Britain (1924). Reports of the Committee upon Injuries of the Nervous System. II. Injuries of the spinal cord and cauda equina. Special Report Series No. 88, pp. 75.

Middleton, G. S., \& Teacher, J. H. (I9i I). Glasg. Med. F. 76, I.

Miller, J. W., \& Schultz, L. R. (I958). Amer. F. Surg. 96, 6I8.

Minor, L. (I904). Handbuch der Pathologischen Anatomie des Nervensystems. vol. 2, p. I029, ed. Flatau, Jacobson and Minor. Berlin: Karger.

Mixter, S. J., \& Osgood, R. B. (I9Io). Ann. Surg. 51, I93.

Motт, F. W. (I888). Brain, I0, 478.

Motт, F. W. (I9I6). Lancet, I, 33I, 44I, 545.

Motт, F. W. (I9I8). Arch. Neurol. Lond. 7, I.

Munro, D. (1943a). New. Engl. F. Med. 229, 9 I9.

Munro, D. (1943b). F. Amer. med. Ass. 122, I055.

Nageotte, M. J. (I899). C. R. Soc. Biol. (Paris), 51, 738.

Nattrass, F. J. (I944). Lancet, 2, 26I.

Nicholas, J. S., \& RudNick, D. (I933). F. exp. Zool. 66, I93.

Nonne (I899). Arch. Psychiat. Nervenkr. 3I, 5 I9. 
OBERsteINER, H. (I879). Ueber Erschütterung des Rückenmarks. Wien med. Fahrb. Quoted by Bickeles, I895. Obersteiner's Arb. 3, IO2.

O’Connell, J. E. A. (I956). Proc. R. Soc. Med. 49, 202.

Ollivier, C.-P. (I837). Traité des Maladies de la Moèlle Épiniere. Chap. 3. Plaies et Contusions ou Compressions Brusques de la Moèlle Épiniere et de ses Membranes, 3rd ed., vol. I, p. 246. Paris: Mequignon-Marvis.

Olsson, S.-E. (1958). F. Neurosurg. 15, 308.

Ornstein, A. M. (1931). Amer. F. med. Sci. 181, 654.

Osnato, M., \& Giliberti, V. (I927). Arch. Neurol. (Chic.), 18, I8I.

OWEN, W. B. (1917). Int. F. Surg. 30, 244.

PAgE, H. W. (I885). Injuries of the Spine and Spinal Cord. 2nd ed. London: Churchill.

PARÉ, A. (I840-4I). Ouevres Complètes d'Ambrose Paré Reues et Collationees. Toutes les Editions avec les Variantes by F. F. Malgaigne. Paris: Bailliere.

Parrot, T. (I870). Un. Med. II, I37.

Paulas, Aegineta (1528). The Seven Books Of Paul of Aegina, ist ed. fol. Venet. Aldus. 3 vols. Trans. Adams, F. London (1844): Sydenham Society.

Payne, E. E., \& Spillane, J. D. (I957). Brain, 80, 57I.

Petren, K. (I9IO). Arch. Psychiat. Nervenkr. 47, 495.

Piatt, J. (1955). f. exp. Zool. 129, 177.

PIERson, R. N. (I923). Surg. Gynec. Obstet. 37, 802.

Pilcher, L. S. (I9IO). Ann. Surg. 5I, 208.

Plewes, B. (1938). Canad. med. Ass. F. 38, 475.

Pool, J. L. (1945). Surg. Gynec. Obstet. 81, 6I 7 .

Rand, C. W., \& Patterson, G. H. (I929). Surg. Gynec. Obstet. 48, 652.

RIDDOCH, G. (1928). Proc. R. Soc. Med. 21, 637.

ROAF, R. (I960). F. Bone f́t. Surg. 42B, 8 IO.

Robson, P. N. (1956). Brit. med. F. 2, 848.

Rodrigues, N. (1897). Ann. Hyg. publ., Paris, 38, 562.

Rogers, W. A. (I957). F. Bone ft. Surg. 39A, 34I.

RosenBERG, A. W. (I957). Bull. Los Angeles neurol. Soc. 22, 79.

Roussy, G., \& Lhermitte. J. (I9I7). Ann. Méd. 4, 458.

Roussy, G., \& Lhermitte, J., \& Cornil, L. (I920). Ann. Méd. 8, 355.

RUGE, C. (1875). Z. Geburtsh. Gymäk. I, 69.

SCAGLiosi, G. (1898). Virchows Arch. path. Anat. 152, 487.

SCARFF, J. E. (1937). N.Y. St. F. Med. 37, 46I.

SCARFF, J.E. (1960). Injuries of the Brain and Spinal Cord and their Coverings. Chap. 19, p. 544, ed. Brock S. London: Cassell.

SCHEINKER, I. M. (I942). F. Neuropath. exp. Neurol. I, I8I.

SCHEINKER, I. M. (I944). Arch. Neurol. (Chic.), 52, 43.

Scheinker, I. M., \& Evans, J. P. (1945). Res. Publ. Ass. Nerv. ment. Dis. 24, 98.

Schmaus, H. (1890). Virchows Arch. path. Anat. 122, 326, 470.

Schmaus, H. (1899). Münch. med. Wschr. Jan i7. No. 3.

Schmaus, H. (1899). Ergebnisse der Allgemeinen Pathologie, Lubarsch und Ostertag. Vierter Jahrgang. Wiesbaden.

SCHNEIDER, R. C. (I95I). F. Neurosurg. 8, 360.

SCHNEIDER, R. C. (I955). F. Neurosurg. I2, 95.

SCHNEIDER, R. C., CHERRY, G., \& PANTEK, H. (1954). F. Neurosurg. II, 546.

SCHNEIDER, R. C., \& KaHN, E. A. (I956). F. Bone ft. Surg. 38A, 985.

SCHNEIDER, R. C., \& KNIGHTON, R. (I959). F. Bone ft. Surg. 4IA, 905.

SCHNEIDER, R. C., Thompson, J. M., \& Bebin, J. (I958). f. Neurol. Neurosurg. Psychiat. 2I, 2 I6.

SPENCER, H. R. (I89I). Trans. obstet. Soc. (Lond.), 33, 270.

SPILler, W. G. (1899). Amer. F. med. Sci. 118, I90.

SPILlER, W. G. (1909). F. nerv. ment. Dis. 36, 60I.

StAUB (1860). Ztschr. f. Staatsarzneikunde, 35.

STCHERBAK, A. (1907). Encéphale, 2, $52 \mathrm{I}$.

STEPHENS, L. B. (1959). F. exp. Zool. 141, 353.

STERN, W. E., \& RAND, R. W. (1959). Amer. F. Obstet. Gynec. 78, 498.

St. John, J. R., \& Rand, C. W. (I953). Bull. Los Angeles neurol. Soc. I8, I.

StoltzenBERG, F. (I9I I). Berl. klin. Wschr. 48, I 74 I. 
Stone, L., \& Roback, H. N. (1937). F. Amer. med. Ass. 108, 1698.

STRATFORD, J. (1957). F. Neurosurg. 14, 97.

Stroebe, H. (1894). Beitr. path. Anat. 15, 383.

Sugar, O., \& GERARD, R. W. (I940). F. Neurophysiol. 3, I.

SWANSON, H. S., \& FinChER, E. F. (1947). F. Neurosurg. 4, 530.

TARLov, İ. M. (1954). Arch. Neurol. (Chic.), 71, 588.

TARlov, I. M. (1957). Spinal Cord Compression. Mechanism of Paralysis and Treatment. p. I30. Springfield: Thomas.

Tarlov, I. M., \& Hertz, E. (1954). Arch. Neurol. (Chic.), 72, 43.

Tarlov, I. M., \& Klinger, H. (I954). Arch. Neurol. (Chic.), 71, 27I.

Tarlov, I. M., Kinger, H., \& Vitale, S. (I953). Arch. Neurol. (Chic.), 70, 8 I 3.

TAYLOR, A. R. (I95I). F. Bone ft. Surg. 33B, 543.

TAYloR, A. R., \& BlACKWOOD, W. (I948). F. Bone ft. Surg. 30B, 245.

Taylor, R. G., \& Gleave, J. R. W. (I957). f. Bone ft. Surg. 39B, 438.

Thompson, J. E. (1923). Ann. Surg. 78, 260.

THORBuRn, W. (I887). Brain, 9, 5 IO.

THORBURN, W. (I888). Brain, I0, 38I.

THORBuRN, W. (I920). Brit. F. Surg. 8, 202.

Thorburn, W., \& Richardson, G. (I9I9). Brit. F. Surg. 6, 48I.

Tureen, L. L.' (1938). Res. Publ. Ass. nerv. ment. Dis. 18, 394.

Van Assen, J. (I908). Z. Orthopäd. Chir. 21, I I7.

WAGNER, W. (1896). Beitr. klin. Chir. 16, 493.

WAGNER, W., \& STOLPER, P. (I898). Deutsche. Chir., Lieferung 40, Die Verletzungen der Wirbelsäule und des Rückenmarks. Stuttgart: Enke.

Walker, A. E., Kollros, J. J., \& Case, T. J. (1944). F. Neurosurg. I, 103.

WALSHE, F. M. R., \& Ross, J. (I936). Brain, 59, 277.

WALTON, (I903). Boston med. surg. F. 149, 445.

WeIss, R. (1877). Arch. klin. Chir. 21, 226.

WindLE, W. F. (1955). Regeneration in the Central Nervous System. Springfield: Thomas.

Windle, W. F. (1962). Basic Research in Paraplegia, p. 5, ed. French, J. D., \& Porter, R. W. Springfield: Thomas.

Wohlfart, G. (196I). Wld. Neurol. 2, I87.

Zeitlin, H., \& Lichtenstein, B. W. (I935). Arch. Neurol. (Chic.), 36, 96. 